Jurnal Pendidikan Biologi 9 (2) (2020) $28-37$
Jurnal Pendidikan Biologi
Journal of Biology Education
elSSN: 2502-3810 $\mathrm{pISSN}$ : 2086-2245

\title{
Pengaruh Metode Mind Mapping Terhadap Kemampuan Pemecahan Masalah dan Hasil Belajar Peserta Didik di Sekolah Menengah Atas
}

\author{
Bella Gustiana Nur, Purwati Kuswarini Suprapto, Suharsono \\ Jurusan Pendidikan Biologi, Fakultas Keguruan dan Ilmu Pendidikan, Universitas Siliwangi, Jl. Siliwangi No. 24, \\ Tasikmalaya, 46115, Jawa Barat, Indonesia
}

\section{INFO ARTIKEL}

\section{Histori Artikel}

Received 7 Juli 2020

Revised 1 Oktober 2020

Accepted 25 Oktober 2020

Published 8 November 2020

\section{Keywords:}

Mind mapping,

Problem solving ability,

The result student

\begin{abstract}
This research is motivated by the ability of problem solving and student learning outcomes which are still low so that a learning method is needed mind mapping.This research was conducted to investigate the influence of mind mapping method of problem solving ability and the result student on ecology concept in grade $\mathrm{X}^{\text {th }}$ grade Math and Science at publich High School Tasikmalaya. The research was carried out in October 2019 until April 2020. The research method used was true experiment. The population of this research was all student of $\mathrm{X}^{\text {th }}$ grade Math and Science as many as 5 classes consist of 160 people. The samples taken used a cluster random sampling technique as many as 2 classes, namely $\mathrm{X}^{\text {th }}$ grade Math and Science 2 as an experimental class and $\mathrm{X}^{\text {th }}$ grade Math and Science 3 as an control class. The data collecting technique used the instrumen of problem solving ability and instrument result student on ecology concept carried out after the learning process. The data analysis technique used was Ancova Test (Analysis of Covariance) dengan bantuan software SPSS 23 for windows pada taraf signifikan $(\alpha)=0,05$. Based on rhe result of the study can be concluded that there is the influence of mind mapping method of problem solving ability and the result student on ecology concept in $\mathrm{X}^{\text {th }}$ grade Math and Science at publich High School Tasikmalaya. The mind mapping method can increase the enthusiasm and understanding of students about the concept of learning.
\end{abstract}

Copyright $(0) 2020$ Universitas Negeri Medan. Artikel Open Access dibawah lisensi CC-BY-4.0 (https://creativecommons.org/licenses/by/4.0)

\section{How to Cite}

Nur, B. G., Suprapto, P. K., \& Suharsono (2020). Pengaruh Metode Mind Mapping Terhadap Kemampuan Pemecahan Masalah dan Hasil Belajar Peserta Didik di Sekolah Menengah Atas Jurnal Pendidikan Biologi, 9(2), 28-37.

\section{PENDAHULUAN}

Menurut Ambawani (2018) bahwa dalam UU No. 20 Tahun 2003 tentang Sistem Pendidikan Nasional bahwa pendidikan merupakan suatu upaya yang dilakukan untuk membimbing serta membantu peserta didik dalam melakukan proses pembelajaran, sehingga akan mewujudkan suasana belajar secara aktif yang dapat meningkatkan potensi peserta didik dalam segi ilmu pengetahuan, jasmani, akhlak serta keterampilan yang diperlukannya baik di masyarakat, bangsa atau negara. Sesuai yang dikatakan oleh Arnyana 
(2020) mengatakan bahwa keterampilan yang harus dimiliki oleh peserta didik ada empat atau yang disebut dengan $4 \mathrm{C}$ yaitu Critical ThinkingandProblem Solving (berpikir kritis dan menyelesaikan masalah), Creativity (kreativitas), Communication Skills (kemampuan berkomunikasi), dan Ability to Work Collaboratively (kemampuan untuk bekerja sama).

Peserta didik tidak hanya mampu menguasai materi pembelajaran tetapi juga harus mampu menyelesaikan permasalahan yang akan dihadapinya nanti. Sehingga dibutuhkan suatu keterampilan yang mampu membantu peserta didik dalam memecahkan suatu permasalahan yaitu kemampuan pemecahan masalah. Sejalan yang dikatakan oleh Nurfatanah (2019) mengatakan bahwa kemampuan pemecahan masalah merupakan kemampuan dasar yang harus dimiliki peserta didik sehingga mampu mengembangkan kemampuan berpikir peserta didik dengan cara memberikan persoalan pemecahan masalah berhubungan dengan fenomena yang terjadi dalam kehidupan sehari-hari berkaitan dengan materi yang diajarkan.

Kemampuan pemecahan masalah peserta didik masih tergolong rendah di SMAN yang terletak di tengah pusat kota Tasikmalaya. Hal ini dilihat dari kemampuan peserta didik dalam menjawab persoalan pemecahan masalah yang tidak sesuai dengan langkah-langkah penyelesaian masalah. Berdasarkan penelitian Desliana (2018) mengatakan bahwa "Peserta didik masih belum bisa menuliskan dan merumuskan masalah yang relevan dengan wacana yang telah disediakan, peserta didik juga belum bisa memberikan solusi-solusi terbaik yang terkait dengan permasalahan yang telah dirumuskan sebelumnya." Artinya, peserta didik masih belum bisa menjawab persoalan terkait pemecahan masalah yang cara penyelesainnya harus menggunakan kaidah ilmiah. Selain itu juga masih terdapat rendahnya hasil belajar yang dicapai oleh peserta didik khususnya pada pembelajaran biologi.

Berdasarkan hasil observasi penulis ketika PLP (Pengenalan Lapangan Persekolahan) di kelas X SMA Negeri yang terletak di tengah pusat kota Tasikmalaya, Kelas X MIPA terdiri dari lima kelas. KKM yang ditetapkan untuk mata pelajaran biologi kelas $\mathrm{X}$ adalah 75 , sedangkan pencapaian nilai beberapa peserta didik rata-rata belum memenuhi standar yang ditentukan. Salah satu penyebab rendahnya KKM tersebut ialah peserta didik yang kurang aktif dan kurang memahami konsep yang diberikan oleh guru. Masalah lain diantaranya, pembelajaran guru hanya menjelaskan konsep pembelajaran menggunakan powerpoint dan melakukan diskusi kelompok sehingga peserta didik kurang aktif dan kurang memahami konsep yang diberikan oleh guru karena pembelajaran terlalu monoton. Sehingga perlu adanya metode pembelajaran yang mampu meningkatkan semangat serta pemahaman peserta didik mengenai konsep pembelajaran.

Salah satu metode yang dapat digunakan dalam proses pembelajaran yaitu metode mind mapping. Metode mind mapping mampu membantu peserta didik dalam menyelesaikan permasalahan yang dilihat dari berbagai sudut pandang serta memudahkan peserta didik untuk memahami dan menghafal konsep yang telah disampaikan oleh guru. "Mind mapping adalah alternatif pemikiran keseluruhan otak terhadap pemikiran linier yang menggapai segala arah dan menangkap berbagai pikiran dari segala sudut. Penerapan metode mind mapping juga dapat membantu mempermudah guru dalam menyampaikan materi pembelajaran dan memperkuat daya ingat peserta didik terhadap materi yang telah diberikan." (Kurniasari, 2015; Michalko, 2009).

Berdasarkan penjelasan tersebut, penulis telah melakukan penelitian mengenai "Pengaruh metode mind mapping terhadap kemampuan pemecahan masalah dan hasil 
belajar peserta didik pada konsep ekologi di kelas X MIPA SMA". Penelitian ini bertujuan untuk mengetahui pengaruh metode mind mapping terhadap kemampuan pemecahan masalah dan hasil belajar peserta didik pada konsep Ekologi kelas X MIPA SMA. Dalam penelitian dengan menggunakan metode tersebut diharapkan dapat meningkatkan kemampuan pemecahan masalah dan hasil belajar peserta didik pada konsep ekologi.

\section{METODE}

Penelitian ini termasuk penelitian kuantitatif dengan metode penelitian true experiment. Variabel bebas dalam penelitian ini adalah metode mind mapping pada konsep ekologi sedangkan variabel terikatnya adalah kemampuan pemecahan masalah dan hasil belajar.

\section{Sampel}

Pengambilan sampel pada penelitian ini menggunakan teknik cluster random sampling. Sampel terdiri atas kelas X MIPA 2 sebagai kelas eksperimen yaitu kelas yang proses pembelajarannya menggunakan metode mind mapping dan kelas X MIPA 3 sebagai kelas kontrol yaitu kelas yang proses pembelajarannya menggunakan metode resume.

\section{Desain Penelitian}

Desain Penelitian menggunakan posttest only control design. Pada desain ini terdapat dua kelompok yang masing-masing dipilih secara acak (random). Desain dapat dilihat pada Tabel 1.

Tabel 1. posttest only control design

\begin{tabular}{lcc}
\hline Kelompok & Perlakuan & Posttest \\
\hline Eksperimen & $\mathrm{X}$ & $\mathrm{O}_{2}$ \\
\hline Kontrol & & $\mathrm{O}_{4}$ \\
\hline
\end{tabular}

\section{Keterangan:}

$$
\begin{aligned}
\mathrm{R}= & \begin{array}{l}
\text { Kelompok eksperimen dan kelompok } \\
\text { kontrol yang diambil secara random } \\
\text { dengan teknik cluster random sampling }
\end{array} \\
\mathrm{X}= & \begin{array}{l}
\text { Perlakuan dengan menggunakan } \\
\text { metode mind mapping }
\end{array} \\
\mathrm{O}_{2}= & \begin{array}{l}
\text { Tes akhirpada kelas kontrol tanpa } \\
\text { menggunakan metode mind mapping }
\end{array} \\
\mathrm{O}_{4}= & \begin{array}{l}
\text { Tes akhirpada kelas kontrol tanpa } \\
\text { menggunakan metode mind mapping }
\end{array}
\end{aligned}
$$

\section{Metode Pengumpulan Data}

Metode pengumpulan data adalah cara yang digunakan untuk mengumpulkan data penelitian. Dalam penelitian ini digunakan beberapa teknik pengumpulan data, yaitu dengan dokumentasi berupa video serta foto saat terjadinya proses pembelajaran berlangsung, metode tes berupa tes tertulis yaitu soal uraian untuk kemampuan pemecahan masalah dan soal pilihan ganda untuk hasil belajar. Hasil tes kemampuan pemecahan masalah dan hasil belajar peserta didik diperoleh dari nilai posttest dan data dianalisis menggunakan uji prasyarat analisis menggunakan uji normalitas dengan uji kolmogorov smirnov dan uji homogenitas dengan levene' test. Kemudian dilanjutkan dengan uji hipotesis menggunakan uji ANCOVA (Analysis of Covariance) yang dibantu perangkat lunak SPSS 23.

\section{HASIL DAN PEMBAHASAN}

Berdasarkan hasil uji ANCOVA yang analisis secara deskriptif dapat diketahui bahwa metode mind mapping memberikan dampak yang positif terhadap peningkatan kemampuan pemecahan masalah dan hasil belajar peserta didik. Artinya, metode ini mampu memberikan pengaruh yang signifikan dalam meningkatkan kemampuan pemecahan masalah dan hasil belajar peserta didik pada konsep ekologi.

Data yang diperoleh dari penelitian ini meliputi data posttest kelas eksperimen yang menggunakan metode mind mapping dan kelas kontrol yang menggunakan metode resume 
pada konsep ekologi di kelas X MIPA SMA Negeri yang terletak di tengah pusat Kota Tasikmalaya.

\section{Kemampuan Pemecahan Masalah}

Berdasarkan penelitian yang telah dilakukan, diperoleh data dari kelas X MIPA 2 sebagai kelas eksperimen yang proses pembelajarannya menggunakan metode mind mapping pada konsep ekologi dengan menggunakan 10 butir soal uraian, dilihat dari hasil tes akhir (posttest) diperoleh data statistik seperti disajikan pada Tabel 2.

Tabel 2. Statistik posttest kemampuan pemecahan masalah kelas eksperimen dan kelas kontrol

\begin{tabular}{lcc}
\hline Statistik & $\begin{array}{c}\text { Kelas } \\
\text { Eksperimen }\end{array}$ & $\begin{array}{c}\text { Kelas } \\
\text { Kontrol }\end{array}$ \\
\hline Jumlah Sampel & 33 & 34 \\
Skor maksimum & 35 & 35 \\
Skor minimum & 25 & 20 \\
Rentang & 10 & 15 \\
Rata-rata & 30,39 & 25,61 \\
Varians & 7,996 & 16,434 \\
Standar deviasi & 2,828 & 4,054 \\
\hline
\end{tabular}

Pada Tabel 2 memperlihatkan hasil penelitian posttest kemampuan pemecahan masalah peserta didik. Kelas eksperimen memiliki rata-rata posttest 30,39 sedangkan kelas kontrol memiliki rata-rata posttest 25,61. Untuk lebih jelasnya ada pada diagram dibawah ini (Gambar 1).

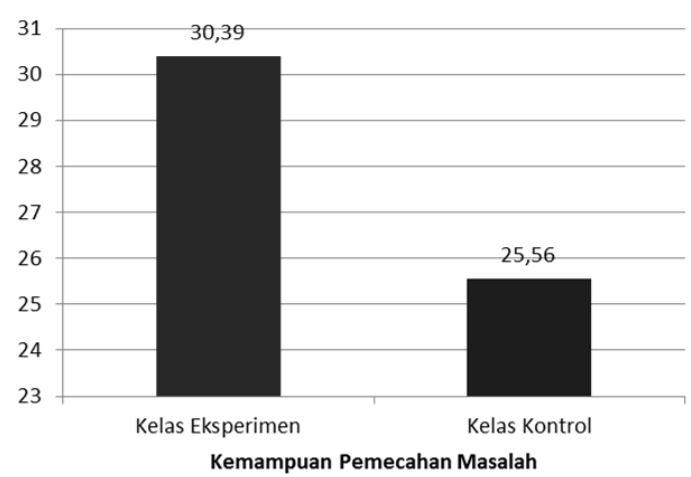

Gambar 1. Diagram Pencapaian Kemampuan Pemecahan Masalah Peserta Didik di Kelas Eksperimen dan Kelas Kontrol
Berdasarkan Gambar 1 menunjukkan bahwa kemampuan pemecahan masalah pada konsep ekologi di kelas eksperimen yang proses pembelajarannya menggunakan metode mind mapping memiliki rata-rata kemampuan pemecahan masalah yang tinggi dibandingkan dengan kelas kontrol yang menggunakan metode resume. Peserta didik mampu memecahkan permasalahan dengan metode mind mapping berdasarkan pemetaan konsep yang dibuat ke dalam suatu karya mind map sehingga melatih potensi kerja otak peserta didik dan mampu memecahkan suatu permasalah dengan berbagai sudut pandang."Kemampuan pemecahan masalah harus dimiliki peserta didik karena fungsi dari kemampuan pemecahan masalah ini dapat membantu peserta didik untuk membuat keputusan yang tepat, cermat, logis dan mempertimbangkan dari berbagai sudut pandang." (Takwin, 2010; Paidi, 2006).

Untuk lebih jelasnya perbandingan skor setiap indikator yang diperoleh peserta didik di kelas eksperimen dan kelas kontrol dapat dilihat pada diagram berikut ini (Gambar 2).

Berdasarkan Gambar 2 memperlihatkan data tertinggi skor posttest kemampuan pemecahan masalah peserta didik pada kelas eksperimen terdapat pada indikator 2 sebesar 3,27 yaitu mendiagnosis masalah dimana dalam indikator ini peserta didik mampu mendiagnosis masalah dengan metode mind mapping, membuat pemetaan konsep sehingga mampu melatih kemampuan mendiagnosis masalah peserta didik, mencari faktor penyebab terjadinya permasalahan dari berbagai sudut pandang melalui mind map yang telah dibuatoleh peserta didik sehingga peserta didik mampu mengembangkan pikirannya dalam memecahkan suatu permasalahan khususnya pada konsep Ekologi. Hal ini menunjukkan kesesuain dengan yang diharapkan oleh penulis karena dari metode mind mapping mampu mengembangkan potensi otak peserta didik yang mampu menangkap pemikiran dari 
berbagai sudut pandang khusunya pada konsep Ekologi. Sejalan yang dikatakan oleh Aprinawati (2016) menyatakan bahwa "Mind Mapping dapat membantu kita untuk banyak hal seperti merencanakan, berkomunikasi, menjadi lebih kreatif, menyelesaikan masalah, memusatkan perhatian, menyusun dan menjelaskan pikiran pikiran, mengingat dengan baik, belajar lebih cepat dan efisien serta melatih gambar keseluruhan." Dari pernyataan tersebut dapat dihubungkan bahwa mind mapping mampu membantu peserta didik dalam penyelesaian suatu permasalahan sehingga dapat memberikan dampak positif terhadap peningkatan kemampuan pemecahan masalah peserta didik.

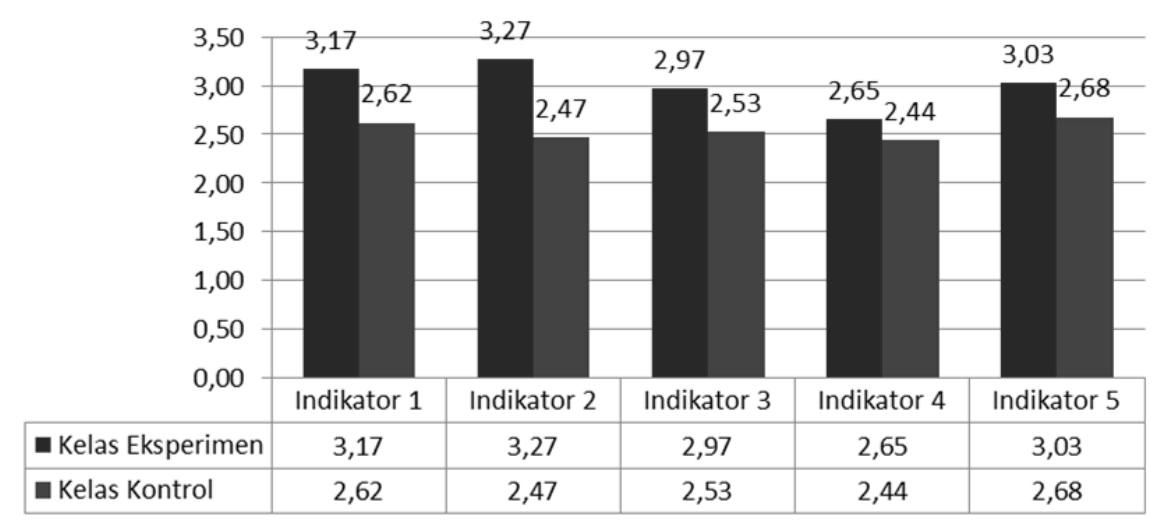

Gambar 2. Diagram Perbandingan Rata-rata Skor Posttest dalam Setiap Indikator Kemampuan Pemecahan Masalah Peserta Didik di Kelas Eksperimen dan Kelas Kontrol

\section{Hasil Belajar}

Sedangkan untuk perbandingan hasil belajar yang diperoleh peserta didik di kelas eksperimen dengan metode pembelajaran mind mapping dan kelas kontrol yang menggunakan metode resume, dapat dilihat pada Tabel 3.

Tabel 3. Statistik posttest hasil belajar kelas eksperimen dan kelas kontrol

\begin{tabular}{lcc}
\hline Statistik & $\begin{array}{c}\text { Kelas } \\
\text { Eksperimen }\end{array}$ & $\begin{array}{c}\text { Kelas } \\
\text { Kontrol }\end{array}$ \\
\hline Jumlah Sampel & 33 & 34 \\
Skor maksimum & 21 & 20 \\
Skor minimum & 12 & 9 \\
Rentang & 9 & 11 \\
Rata-rata & 16,73 & 13,88 \\
Varians & 6,767 & 9,860 \\
Standar deviasi & 2,601 & 3,140 \\
\hline
\end{tabular}

Tabel 3 memperlihatkan hasil penelitian posttest hasil belajar peserta didik. Pada kelas eksperimen memiliki rata-rata posttest hasil belajar yaitu 16,73 sedangkan pada kelas kontrol memiliki rata-rata posttest yaitu 13,88.
"Melalui mind mapping siswa akan lebih mampu untuk mengekspresikan dirinya dalam membuat suatu hasil karya berupa catatan yang menarik dan kreatif.Materi yang dicatat siswa dalam bentuk mind map memperlihatkan peta pemikiran siswa dalam memahami materi, sehingga peta atau jalur yang dibuat secara unik dan kreatif dapat dipahami sendiri oleh siswa." (Munandar, 2016; Silaban \& Masita, 2012).

Berdasarkan uraian tersebut proses pembelajaran dengan menggunakan metode mind mapping cocok diterapkan untuk meningkatkan hasil belajar, khusunya pada konsep ekologi. Hal ini dibuktikan dengan pencapaian skor rata-rata hasil belajar peserta didik di kelas eksperimen yang melebihi KKM, dapat dilihat dalam Gambar 3.

Berdasarkan Gambar 3 dapat disimpulkan bahwa nilai rata-rata pada kelas kontrol yang menggunakan metode pembelajaran resume skor hasil belajar yang didapatkan oleh peserta didik cenderung lebih rendah yaitu 63,24 
sehingga tidak dapat memenuhi nilai KKM yang telah ditetapkan sedangkan pada kelas eksperimen hasil belajar peserta didik telah memenuhi bahkan melebihi KKM yaitu 76,03 dengan KKM yang harus dipenuhi sebesar 76 . Artinya, selama proses pembelajaran peserta didik dapat menyerap konsep yang disampaikan dan dipelajari dengan menggunakan metode mind mapping. Bahkan menurut Murni et al. (2014) dalam penenelitiannya mengatakan bahwa "Metode Mind Mapping memiliki pengaruh yang lebih baik dibandingkan dengan metode pembelajaran Konvensional. Perbedaaan yang signifikan ini salah satunya disebabkan oleh manfaat nyata dari metode pembelajaran mind mapping. Pada metode pembelajaran mind mapping, siswa ikut berpikir dan aktif terlibat dalam mengkonstruksi pengetahuannya sendiri, sehingga siswa menjadi lebih kreatif dan kritis, dan disamping itu proses pembelajaran yang mereka alami menjadi lebih bermakna dibandingkan dengan konstruksi pengetahuan yang ditanamkan dengan metode ceramah." Berdasarkan uraian tersebut dapat ditarik sebuah kesimpulan bahwa metode mind mapping dapat meningkatkan hasil belajar peserta didik pada konsep ekologi.

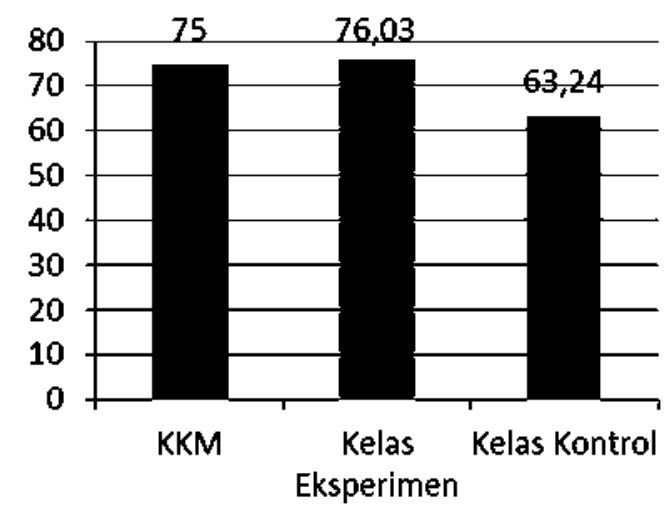

Gambar 3. Diagram Pencapaian Nilai KKM Hasil Belajar Peserta Didik di Kelas Eksperimen yang Menggunakan Metode Mind Mapping

\section{Kemampuan Pemecahan Masalah dan Hasil Belajar}

Data dari kedua kelompok telah diambil dari populasi yang berdistribusi normal dan kedua varians homogen, maka pengujian dilanjutkan dengan menggunakan uji Ancova (Analysis of Covarience) untuk mengetahui pengaruh perlakuan terhadap peubah respon dengan mengontrol peubah lain yang kuantitatif. Ringkasan perhitungan uji hipotesis disajikan pada Tabel 4.

Berdasarkan Tabel 4 memperlihatkan bahwa hasil analisis data ringkasan uji Ancova untuk pengaruh metode pembelajaran terhadap kemampuan pemecahan masalah peserta didik didapatkan nilai signifikansi pada bagian kemampuan pemecahan masalah sebesar 0,035. Karena hasil tersebut lebih kecil dari taraf signifikansi 0,05 maka Ho ditolak. Hal ini berarti bahwa pada tingkat kepercayaan 95\% dapat dikatakan ada pengaruh metode pembelajaran terhadap kemampuan pemecahan masalah peserta didik.

Selanjutnya dilakukan pengujian untuk mengetahui pengaruh metode pembelajaran terhadap skor hasil belajar yang diperoleh peserta didik. Pengujian ini dilakukan dengan menghilangkan pengaruh kemampuan pemecahan masalah dari metode mind mapping. Dari hasil pengolahan terlihat bahwa taraf signifikansi pada bagian metode pembelajaran adalah 0,000 . Karena nilainya jauh dibawah 
0,05 maka Ho ditolak. Sehingga dapat disimpulkan bahwa tanpa pengaruh kemampuan pemecahan masalah, pada tingkat kepercayaan $95 \%$ ada pengaruh metode mind mapping terhadap hasil belajar yang diperoleh oleh peserta didik.Selain itu, untuk mengetahui metode mind mapping terhadap kemampuan pemecahan masalah dan hasil belajar peserta didik dapat diketahui bahwa taraf signifikansi pada bagian corrected model sebesar 0,000 karena nilai signifikansi kurang dari 0,05 maka Ho ditolak. Hal ini berarti bahwa pada tingkat kepercayaan $95 \%$ dapat dikatakan bahwa secara simultan metode pembelajaran berpengaruh terhadap kemampuan pemecahan masalah dan hasil belajar peserta didik.

Secara operasional hasil pengujian tersebut juga dapat dibuktikan melalui data deskriptif yaitu pada kelas eksperimen nilai rata-rata posttest kemampuan pemecahan masalah adalah sebesar 30,39 dan nilai rata-rata posttest hasil belajar sebesar 16,73. Sedangkan pada kelas kontrol nilai rata-rata posttest kemampuan pemecahan masalah adalah sebesar 25,61 dan nilai rata-rata posttest hasil belajar sebesar 13,88 .

Tabel 4. Ringkasan Hasil Uji Ancova Kemampuan Pemecahan Masalah dan Hasil Belajar

\begin{tabular}{lccccr}
\hline \multicolumn{1}{c}{ Sumber } & Jumlah Kuadrat Tipe 3 & (db) & Kuadrat rata-rata & F & Sig. \\
\hline Nilai Simultan & $168,642^{\mathrm{a}}$ & 2 & 84,321 & 10,850 &, 000 \\
Intersep & 448,099 & 1 & 448,099 & 57,658 &, 000 \\
Kemampuan Pemecahan Masalah & 35,893 & 1 & 35,893 & 4,618 &, 035 \\
Metode Pembelajaran & 165,560 & 1 & 165,560 & 21,303 &, 000 \\
Kesalahan & 497,388 & 64 & 7,772 & & \\
Total & 16347,000 & 67 & & & \\
Nilai Korelasi & 666,030 & 66 & & & \\
\hline
\end{tabular}

\section{Keterangan:}

db: derajat bebas; F: nilai F hitung; Sig.: Signifikansi

Berdasarkan penelitian yang telah penulis lakukan di kelas eksperimen yang proses pembelajarannya menggunakan metode mind mapping, setelah diuji dengan Ancova (Tabel 4) untuk kemampuan pemecahan masalah nilai signifikasi 0,035 karena hasil nilai signifikasi < 0,05 . Sehingga kesimpulan hipotesi yang didapat adalah tolak Ho yang berarti terdapat pengaruh metode mind mapping terhadap kemampuan pemecahan masalah peserta didik. Adanya pengaruh tersebut karena metode mind mapping dapat meningkatkan potensi kerja otak sehingga peserta didik mampu memecahkan permasalahan yang secara terperinci. "Mind mapping dapat meningkatkan kemampuan siswa dalam berpikir karena memadukan dan mengembangkan potensi kerja otak, sehingga perhatian terpusat pada subjek serta mampu mengembangkan cara pengaturan pikiran secara terperinci." (Ristiasari 2012; Naim 2006)
Secara operasional hasil pengujian tersebut juga dapat dibuktikan melalui data deskriptif yaitu pada kelas eksperimen nilai rata-rata posttest kemampuan pemecahan masalah adalah sebesar 30,39 dan nilai rata-rata posttest hasil belajar sebesar 16,73. Sedangkan pada kelas kontrol nilai rata-rata posttest kemampuan pemecahan masalah adalah sebesar 25,61 dan nilai rata-rata posttest hasil belajar sebesar 13,88. Berikut diagram skor rata-rata posttest kemampuan pemecahan masalah dan hasil belajar peserta didik (Gambar 4).

Berikut diagram skor rata-rata posttest kemampuan pemecahan masalah dan hasil belajar peserta didik (Gambar 4).

Kesimpulan dari diagram (Gambar 4) didapatkan bahwa perbedaan skor rata-rata kemampuan pemecahan masalah dan hasil belajar peserta didik di kelas eksperimen yang proses pembelajarannya menggunakan metode 
mind mapping jauh lebih tinggi dibandingkan dengan skor rata-rata kemampuan peemcahan masalah dan hasil belajar peserta didik di kelas kontrol yang proses pembelajarannya menggunakan metode resume. Hal tersebut menunjukkan adanya pengaruh metode mind mapping terhadap peningkatan kemampuan pemecahan masalah dan hasil belajar peserta didik pada konsep ekologi.

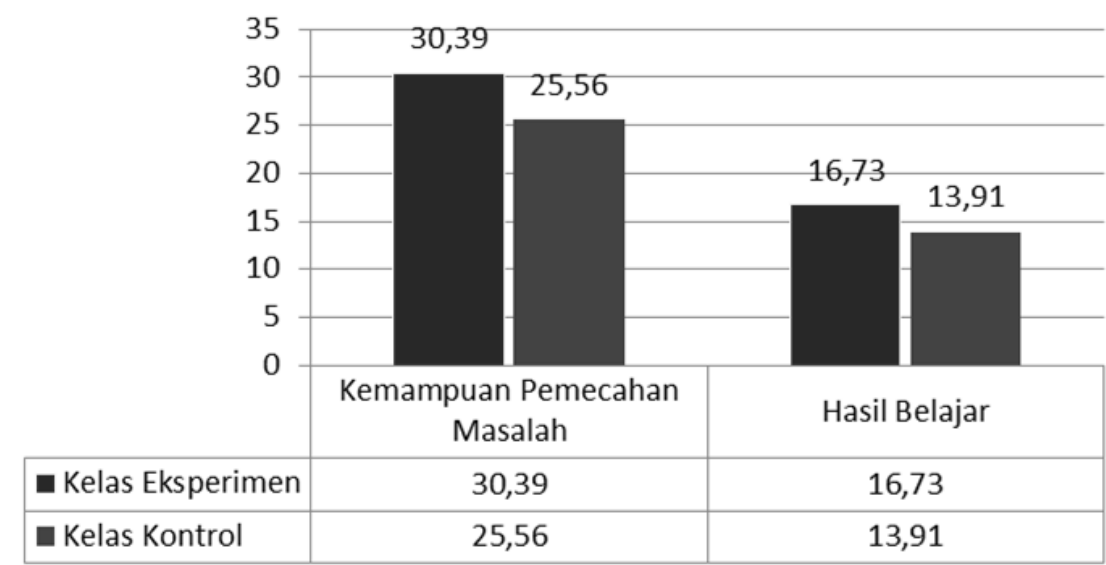

Gambar 4. Skor Rata-rata Posttest Kemampuan Pemecahan Masalah dan Hasil Belajar Peserta Didik Kelas Eksperimen dan Kelas Kontrol

Mind mapping mampu membantu meningkatkan hasil belajar peserta didik karena lebih mudah memahami konsep yang saling berhubungan dan berkaitan, pembuatan mind mapping juga tidak membutuhkan banyak lembar kertas dan seluruh konsep dapat tercatat dalam satu lembar kertas saja, sehingga peserta didik dapat mempelajarinya secara efisien."Kegiatan membuat mind map ini melibatkan pergerakan tangan untuk membuat peta, jalur dan koneksi antar konsep. Proses pergerakan tangan yang terus-menerus untuk menghubungkan konsep ini dapat meningkatkan kerja otak pada siswa, sehingga kemampuan untuk memahami konsep pada materi pelajaran dapat berlangsung maksimal." (Munandar 2016; Rahmawati \& Asri, 2014).

Selain itu, mind mapping ini merupakan metode pembelajaran yang mampu meningkatkan kemampuan peserta didik dalam memahami suatu konsep pembelajaran karena metode ini merupakan teknik mencatat secara kreatif sehingga peserta didik tidak mudah bosan dalam proses pembelajaran. Selain itu juga, dalam pembuatan mind mapping menggunakan peserta didik menggunakan ideide pokok dari peserta didik itu sendiri sehingga lebih mudah dipahami. "Melalui mind mapping siswa akan lebih mampu untuk mengekspresikan dirinya dalam membuat suatu hasil karya berupa catatan yang menarik dan kreatif.Materi yang dicatat siswa dalam bentuk mind map memperlihatkan peta pemikiran siswa dalam memahami materi, sehingga peta atau jalur yang dibuat secara unik dan kreatif dapat dipahami sendiri oleh siswa." (Munandar, 2016; Silaban \&Masita, 2012).

Berdasarkan uraian di atas dapat ditarik kesimpulan bahwa peningkatan kemampuan pemecahan masalah dan hasil belajar disebabkan karena metode mind mapping merupakan suatu metode yang mampu mengembangkan semangat peserta didik dalam pembelajaran dan membantu peserta didik dalam hal teknik pencatatan kreatif. Hal tersebut dapat dibuktikan dari salah satu hasil karya mind mapping yang telah dibuat oleh 
peserta didik pada pertemuan ke 2 sub konsep aliran energi dan piramida ekologi (Gambar 5).

Berdasarkan Gambar 5 dapat dilihat bahwa mind mapping merupakan teknik pencatatan kreatif karena memadukan warna dalam pembuatannya, menggunakan gambar dan simbol, serta peserta didik juga menggunakan penjelasan konsep sesuai yang dipahami atau menggunakan kata-kata sendiri. Menurut Faelasofi et al. (2015) menyatakan bahwa "Metode pembelajaran mind mapping mampu membuat suasana pembelajaran yang menarik, meotivasi siswa, dan menyenangkan ketika siswa mempelajari materi." Sejalan dengan uraian tersebut, proses pembelajaran menggunakan metode mind mapping mampu meningkatkan semangat peserta didik dalam pembelajaran, memudahkan peserta didik dalam mengingat dan memahami suatu konsep sehingga mampu memecahkan permasalahanpermasalahan yang dihadapinya berdasarkan konsep yang dimilikinya dan dikaitkan dengan kehidupan sehari-hari.

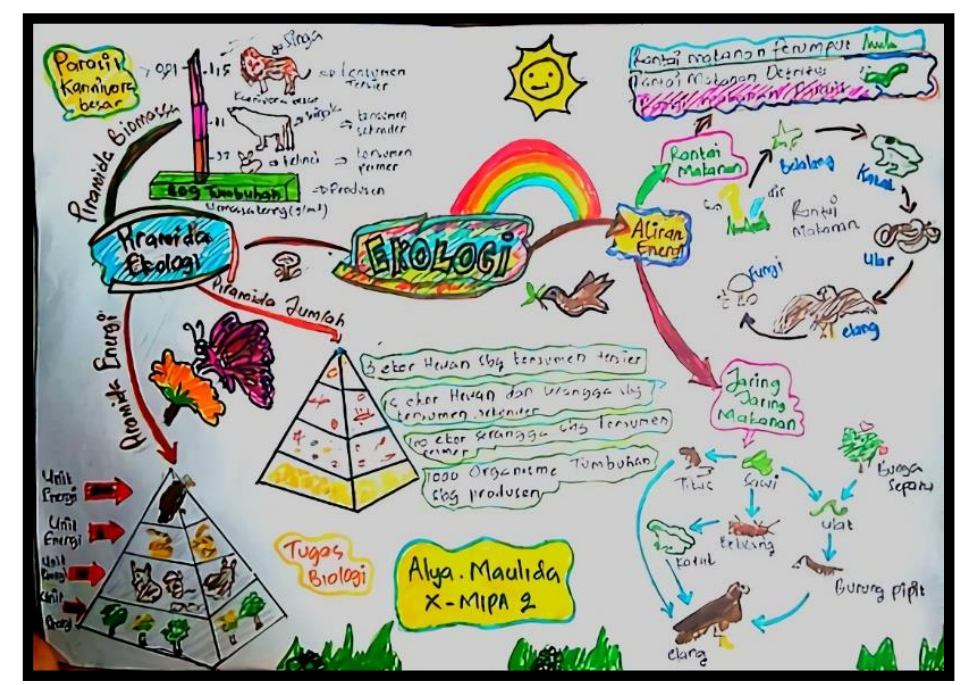

Gambar 5. Salah satu Hasil Karya Mind Mapping Peserta Didik

Mind mapping merupakan teknik pencatatan kreatif karena memadukan warna dalam pembuatannya, menggunakan gambar dan simbol, serta peserta didik juga menggunakan penjelasan konsep sesuai yang dipahami atau menggunakan kata-kata sendiri. Hal tersebut mampu membuat peserta didik lebih memahami konsep yang telah diberikan oleh guru, mampu memecahkan permasalahan-permasalahan yang dihadapinya berdasarkan konsep yang dimilikinya dan dikaitkan dengan kehidupan sehari-hari. Berdasarkan tersebut, dapat disimpulkan kelebihan mind mapping mampu membantu meningkatkan hasil belajar peserta didik karena lebih mudah memahami konsep yang saling berhubungan dan berkaitan, pembuatan mind mapping juga tidak membutuhkan banyak lembar kertas dan seluruh konsep dapat tercatat dalam satu lembar kertas saja, sehingga peserta didik dapat mempelajarinya secara efisien. Bahkan pernyataan tersebut juga didukung bahwa "kegiatan membuat mind map ini melibatkan pergerakan tangan untuk membuat peta, jalur dan koneksi antar konsep. Proses pergerakan tangan yang terus-menerus untuk menghubungkan konsep ini dapat meningkat-kan kerja otak pada siswa, sehingga kemampuan untuk memahami konsep pada materi pelajaran dapat berlangsung maksimal." (Munandar, 2016; Rahmawati \& Asri, 2014). 
Kekurangan mind mapping yaitu dalam pembuatan mind mapping peserta didik kesulitan untuk membuat kata kunci dari konsep yang digunakan untuk mind mapping. Selain itu, jika pembelajaran terjadi langsung di dalam kelas dan dilakukan secara berkelompok, tidak semua peserta didik dapat aktif dalam pembuatan mind mapping. "Kelemahan mind map yaitu hanya siswa yang aktif yang terlibat, tidak sepenuhnya murid yang belajar, dan mind map siswa bervariasi sehingga guru akan kewalahan memeriksa Mind Map siswa." (Ningsih et al., 2012; Kurniawati, 2010).

\section{KESIMPULAN}

Berdasarkan hasil penelitin, pengolahan data dan pengujian hipotesis maka dapat disimpulkan bahwa metode mind mapping mampu meningkatkan kemampuan pemecahan masalah peserta didik pada konsep ekologi di kelas X MIPA SMA, metode mind mapping mampu meningkatkan hasil belajar peserta didik pada konsep ekologi di kelas X MIPA SMA, dan adanya metode pembelajaran yang bervariasi mampu meningkatkan semangat serta pemahaman peserta didik mengenai konsep pembelajaran.

\section{DAFTAR PUSTAKA}

Ambawani, C.S.L. (2018). Peningkatan Hasil Belajar Sosiologi Materi Konflik Sosial melalui Model PBL dan NHT bagi Peserta Didik Kelas XI IPS 4 SMA Negeri 6 Surakarta Tahun Pelajaran 2017/2018.Jurnal Pendidikan Empirisme, 24(5), 15-24. https://doi.org/10.31004/basicedu.v2i1.132.

Aprinawati, I. (2018). Penggunaan Model Peta Pikiran (Mind Mapping) untuk Meningkatkan Pemahaman Membaca Wacana Siswa Sekolah Dasar. Jurnal Basicedu, 2(1), 140-147.

https://doi.org/10.31004/basicedu.v2i1.132.

Arnyana, I.B.P. (2020). Pembelajaran untuk Meningkatkan Kompetensi 4C (Communication,
Collaboration, Critical Thinking dan Creative Thinking) untuk Menyongsong Era Abad 21. Prosiding Konferensi Nasional Matematika dan IPA Universitas PGRI Banyuwangi, 1(1), 1-13.

Buzan, T. (2012). Buku Pintar Mind Map. Jakarta : PT. Gramedia Pustaka Utama.

Desliana, M. (2018). Kemampuan Pemecahan Masalah Siswa Kelas X SMAN 4 Tanjungpinang.Skripsi. Program Studi Pendidikan Biologi, Fakultas Keguruan dan Ilmu Pendidikan, Universitas Maritim Raja Ali Haji.

Faelasofi, R., Arnidha, Y., \& Istiani, A.. (2015). Metode Pembelajaran Mind Mapping untuk Meningkatkan Kemampuan Komunikasi Matematik Siswa Dalam Pemecahan Masalah Matematika. Jurnal e-DuMath. 1(2), 122-136.

Kurniasari, W. (2014). Peningkatan Komunikasi dan Kemampuan Pemecahan Masalah Matematika dengan Strategi Mind Mapping. Skripsi. Universitas Muhammadiyah Surakarta.

Munandar, R.A. (2016). Pengaruh Pembelajaran Mind Map Terhadap Hasil Belajar Biologi Siswa Kelas X di SMAN Kebakkramat Semester Genap Tahun Pelajaran 2015/2016.Skripsi.Program Studi Pendidikan Biologi, Fakultas Keguruan dan Ilmu Pendidikan,Universitas Muhammadiyah Surakarta.

Murni, I. D. A. M., Dantes, N., \& Lasmawan, I. W. (2014). Pengaruh Metode Pembelajaran Mind Mapping terhadap Hasil Belajar IPS Ditinjau dari Motivasi Berprestasi pada Siswa Kelas IV SD. Jurnal Pendidikan Dasar Indonesia, 4(1),1-12.

Ningsih, W.C., Marzuki, M., \& Marli, S. (2012). Pengaruh Sistem Pembelajaran Mind Map terhadap Pemerolehan Belajar IPS Kelas V SDN 11 Pontianak. Jurnal Pendidikan dan Pembelajaran Khatulistiwa, 1(1),1-14.

Nurfatanah, Rusmono dan Nurjannah. (2018). Kemampuan Pemecahan Matematika Siswa Sekolah Dasar. Prosiding Seminar dan Diskusi Nasional Pendidikan Dasar. Hal. 546-551.

Paidi. (2010). Model Pemecahan Masalah dalam Pembelajaran Biologi di SMA. Seminar Nasional. Hal 1-10.

Ristiasari, T., Bambang Priyono dan Sri Sukaesih. (2012). Model Pembelajaran Problem Solving dengan Mind Mapping Terhadap Kemampuan Berpikir Kritis Siswa. Unnes Journal of Biology Education. 1 (3), 34-41. 